\title{
Academic Words and Academic Capitalism ${ }^{1}$ Palabras académicas en el capitalismo académico
}

Michael Billig

Loughborough University, M.G.Billig@Iboro.ac.uk

\section{Historia editorial}

Recibido: 04/10/2012

Aceptado: 16/10/2012

\section{Keywords}

Academic capitalism

Writing style

Nominalization

Academic publishing

\begin{abstract}
This paper suggests that it is the best and worst of times for academic work. It is the best of times because there are more academics publishing than ever before. It is the worst of times because there is much unnecessary publication. Working in the competitive conditions of academic capitalism, academics feel impelled to keep publishing, whether or not they have anything to say. The pressures to publish continually and to promote one's own approach are reflected in the way that social scientists are writing. Academics use a noun-based technical language, which is less precise than ordinary language. Postgraduates are taught this way of writing as a precondition for entering the social sciences. In this way, the nature of academic capitalism not only determines the conditions under which academics are working but it affects the way that they are writing.
\end{abstract}

\section{Resumen}

\section{Palabras clave}

Capitalismo académico

Estilo de escritura

Normalización

Publicación académica

\begin{abstract}
Este artículo sugiere que esta época es la mejor y peor para la labor académica. La mejor en cuanto hay más publicaciones académicas que nunca. Y la peor porque sobra mucho de estas publicaciones. Trabajando en las condiciones competitivas del capitalismo académico, los académicos se sienten en la necesidad de continuar publicando, independientemente de que tengan algo que decir. Las presiones de publicar continuamente y promover la propia perspectiva se reflejan en la manera en la que los científicos sociales están escribiendo. $Y$ es que los académicos utilizan un lenguaje técnico basado en sustantivos, con una precisión menor a la del lenguaje ordinario. Los estudiantes de postgrado han sido educados en esta manera de escribir como una condición previa a iniciarse en las ciencias sociales. Así, la naturaleza misma del capitalismo académico no sólo determina las condiciones en las que los académicos trabajan, sino que también afecta su manera de escribir.
\end{abstract}

It is a great pleasure for me to be here, to give the opening paper of the conference and also to share this session with my old friend Peter Golding. I want to take up the opportunity to embarrass Peter as much as I can. This conference has been officially organized to celebrate the anniversaries of two research groups in the department of social sciences: the Discourse and Rhetoric Group (DARG) and the Communication and Media Research Group (CAMARG). I was ask to talk about the history and some of the achievements of DARG. But actually I don't want a say anything about this mainly because I think it would be taking advantage from those who have come here to Loughborough, especially those who have travelled here from a long distance. But you haven't all travelled this far to listen to people from Loughbourough saying 'Oh we are marvelous! Haven't we done fantastic things? Don't you wish you

Billig, Michael (2013). Academic Words and Academic Capitalism. Athenea Digital, 13(1), 7-12. Disponible en http://psicologiasocial.uab.es/athenea/index.php/atheneaDigital/article/view/1108-Billig

\footnotetext{
1 Transcription of the conference held in Loughborough University in March 2012 to celebrate 25 years of the Discourse and Rhetoric Group (DARG) and 10 years of the Culture and Media Analysis Research Group (CAMARG). Available at http://vimeo.com/40710766
} 
worked here?' Because I was asked to talk about DARG's achievements, please could I ask Loughborough people to pretend that I boasted and boasted about Loughborough's achievements until my heart burst? I would ask the non-Loughborough people to please notice that I haven't done the boasting that I should have done.

I have another reason for avoiding the sort of boasting talk which is expected at such an occasion. This is because I am concerned about the way academics are conventionally using language and I am particularly concerned about the state of universities today. Recently there have been a lot of people, who have done research about the state of universities today and who have written critically about what is occurring in higher education here and across the world. I think that the term 'academic capitalism' is an apt way to describe what is happening to institutions of tertiary education. All who work in higher education will be aware of the continuing financial pressures that are turning institutions of higher education into businesses. There has been a lot of good research, particularly from critical discourse analysts, about the ways that those who manage universities and who hold senior positions within universities are using promotional language as they operate within an increasingly competitive and entrepreneurial environment. The problem with such discursive research, or more generally with the research into 'academic capitalism' lies in what conventionally ignored. By and large, the researchers examine the language of others - how, for example, managers and those in the publicity departments of universities use promotional language and choose linguistic formulations that resemble those used by advertisers.

Much of this research is excellent but it omits one crucial factor: the language that academics are using as part of their academic work. We need to look at our own language to see how we as academics have gone along with the entrepreneurial spirit and how academic capitalism is affecting the ways that we write as academics. It is as if we imagine ourselves to be untouched by the wider patterns of social life. It is an illusion to that the entrepreneurial conditions of life, in which we are working, are not affecting, even corrupting, intellectual inquiry. As social scientists, we will all acknowledge that social and economic forces affect the way that people use language. Therefore, it would be totally inappropriate for me to have this view and to stand here and say words to the effect that 'Haven't Loughbourough done wonderfully and all our research groups successful?' It would run counter to the message that we should worry about the ways that the entrepreneurial and promotional culture has been affecting university life. Also if I just concentrate on saying how wonderful we were I would miss this golden opportunity of embarrassing Peter Golding.

I want to start by misquoting Charles Dickens. For universities today it is the best of times and also is the worst of times. Is the best of times because there has been a huge expansion globally of tertiary education, in the past twenty years. There's more students going to universities, there are more universities, and with more universities there are more academics. Tertiary education has grown in virtually every country, quite substantially in the last fifteen twenty years. In fact, social scientists have formulated a term to describe this: they talk about 'the massification' of higher education. Actually it is the terms like 'massification' and other apparently technical terms ending in -ification and or -ization, which social scientists are using in such profusion but which I find deeply problematic. A term like 'massification' sounds very impressive and technical. Actually it is used in very imprecise ways, with academics unable to agree what percentage of young people receiving tertiary education constitutes 'massification'. A term like 'massification' seems to offer solutions to the question 'why has this expansion of education occurred?' If we say that it has occurred because of the processes of massification, we might sound impressive, as if we know things that non-speicalists do not. However, we resemble the Aristotelian 
scholars who Molière parodied. 'Why does opium make us tired?' the scholar is asked. The scholar replies, as if giving a profound insight, 'Because it has dormative powers.'

We need not merely say that there is more higher education because there has been massification? In the social sciences we can call upon other -isations and -ifications to produce apparent profundities. We can refer to the totalization of financialization leading to the commercialization and entrepreneurialization etc. of higher education. Moreover we could say that this represents the language of reification, by which people and their actions are turned into things. But notice how we try to explain this by using another word, reification which is exactly the same sort of word, and, thus, creates the same sort of problem namely, we are talking about 'reification' as if it were a thing, not actions that people take.

Nowadays, there is a seemingly never ending expansion of research in higher education. This expansion of research is not just due to there being more academics in higher education system, but the academics in higher education are doing more research than ever before, and this means that they are publishing more than ever. This is happending throughout the higher education system. Academics, who work in institutions which a generation ago did not encourage research, are now publishing and doing research; and academics working in traditional research universities, are actually publishing more head than ever before. It seems as if everyone wants not just to publish and to publish again and again. Institutions want us to publish because research is another way of generating money; moreover research in the academic world brings status. The academic world may be full of status and snobbery and today status and snobbery do not matter in themselves but matter because they bring more money. The higher status that your institution possesses, the more students and grants that it can attract. For individual academics, we can get positions, promotions and increased salary if we publish. So, everyone wants to publish and everyone can publish. If you can't get your papers into an established journal, you and your friends can set up a journal on the internet to publish your own work.

So in this sense, it is the best of times for academic publishing, but is also the worst of times. Our work is being constantly monitored by our managers, who keep auditing what we produce. However much we do, the managers will want us to do even more. So, we have to publish voluminously and in the so-called best journals. This means that we have to tailor our writing so it might get accepted by the journals which are considered to have high impact, for the big rewards in academic life come to those who publish in 'high impact journals'; 'high impact' is not an academic judgment but is a rating that is computed mathematically, based on the number of citations that the journal's articles receive within the first five years of their publication.

All this means that academics now have to develop a key academic skill that the scholars of old did not require. I particularly wish to address the postgraduates in the audience, when I tell them that there is a key skill that they must acquire if they want to be successful in their academic careers. This is the ability to keep publishing and particularly the skill to be able to publish, especially when you have absolutely nothing to say.

As a result there is a lot of unnecessary publishing going on. A further result, which is occurring as a consequence, is there is too much being published for any single individual to keep up with their reading even in restricted fields. It is impossible for academics to read everything within their discipline. A hundred or so years ago, it was possible for a psychologist or sociologist to read nearly everything that was being written in those disciplines., Now you have to select a very narrow area as your area of expertise, and even then it can be difficult to keep up your reading, because the stuff is just coming, more and more every day. In consequence, academics have to read more and more narrowly, with the result that we are all becoming experts in smaller and smaller areas. The academic world is not just a highly segmented 
place, but there is increasing competition between the segmented areas. In this respect, the world of academia reassembles the world of the mass media. There are more programmes being transmitted on television, more music being broadcast than ever before. People cannot possibly listen to or watch all that is on offer but they have to select what to watch or listen to. The result is that, although there is a greater variety of material available, people are becoming narrower and narrower in their viewing and listening habits. You don't have to watch things or listen to music that you don't like. If you like country and western music, or soul music from a particular decade, you can listen to it all day long without having to sample anything else. Academics are in a similar position. There is more for us to read, but we find ourselves reading more and more narrowly. In this way, if we follow a particular sub-discipline or approach, we can ignore everything that falls outside our particular area of so-called expertise. It is as if we know what we like and we don't want to bother with anything else.

This relates to another familiar feature about the modern academic world, particularly the world of the social sciences: we all must have an approach. It is not sufficient that we try to look at the world directly, but we must look at it through an approach. I'm sure there will be a lot of really excellent talks at this conference will start with words to the effect: 'I'm going to look at the topic $X$, and I'm taking the approach of $Y$ to do $Z$ and, of course, by taking approach $Y$ or $Z$, I will be criticizing the approach $M$ or N'. Taking an approach in the social sciences often means using a particular set of technical words. In fact, you can identify the approach of a given speaker or writer by the technical terms which they use. If I just say a few words like 'governmentality', 'mediatization' or 'transition relevance place' you'll know what approach I'm referring.

It is a feature of contemporary academic writing, both in the natural and the social sciences, that the vast majority of technical terms are nouns. Very few of the technical terms that we use regularly are verbs thus, sociologists will explore 'reification', rather than people reifying. Often academics fit nouns together into formal noun phrases, without any intervening prepositions. This is particular feature of modern academic writing, as well as bureaucratic language, which was much rarer a hundred years ago and which some linguists claim to be a distinctive feature of modern languages. In the social sciences, we regularly string together three nouns in a row, in order to denote an apparent social phenomena: things like 'group categorisation processes' or 'membership categorization devices'. Social scientists do this, regardless of their particular approaches. If everyone needs an approach, then postgraduates also need to acquire the technical vocabulary that the approach claims as its own.

I have said that every social scientist needs to have an approach, but actually l'm simplifying: everyone needs two approaches. It's like the old Jewish joke: 'Every Jew needs two synagogues: the synagogue that you go to and the synagogue you don't go to'. And every academic need two approaches, the approach they take and the approach that they don't take. The latter is the approach that their chosen approach has taken against. The problem with academic success today is that the more successful an approach is, the more supporters it attracts and the more publications will be published by those supporters. This means that there will be more for recruited postgraduates to read, if they want to become part of that approach. The postgraduates will often start with a limited knowledge of the area that they are studying and the approach that they hope to use. As part of the process of becoming a full academic, they will learn the appropriate technical terminology, including the strings of nouns, for their area. They will learn not just the nouns and noun phrases that they should use, but also those that they should not use, except to be rude about. This is part of learning the approach they are taking and the approach they are not taking. 
The problem with academic success is that because there's so much that postgraduates must read within their chosen approach, the less they will know about the approach that they do not take, the approach that they imagine themselves to be combating. At this point, I will mention discursive psychology, not in the way that my colleagues hoped I would talk about it. After I came to Loughborough over twenty-five years ago, a group of us began thinking about producing a different sort of social psychology from the social psychology which we had been taught. We were interested in studying language, particularly rhetoric, discourse and the language used in social interaction, in order to build different forms of social psychology. In doing this, we were rejecting cognitive social psychology or the assumptions of cognitive psychology, which we ourselves had been taught. Our familiarity with the cognitive approach had lead us to the conclusion there was something wrong with it.

Now, as the discursive approach to psychology has developed, and as we ourselves publish more and more stuff, postgraduates, who come to Loughborough to study discursive psychology, have more and moiré to read. We tell them 'is important that you read this and this and this and this and this and this and this and this! And when the next edition of this journal appears, then you must read that' and so on. Amongst all the things that the postgraduates must is that they are not taking the approach of cognitive psychology - after all, they must learn that discursive psychologists reject the cognitive approach. However, we don't want our postgraduates to spend their precious time reading cognitive psychology. In effect, we say them 'There isn't time to read all that stuff, because you must read more and more and more what we and our colleagues have written'. Therefore, because of academic success, we educate our postgraduates to behave like the readership of right-wing tabloid newspapers, who dislike certain others so much that they have never met any. Our postgraduates are taught to dislike cognitive psychology so much that they know very little about it. And we certainly do nothing to disturb this dislike.

We like to think that we are unaffected by the wider entrepreneurial culture in which we work. Or if we are affected, then we can preserve our academic and work to remain uncontaminated by this culture. I suspect if we look closely that our writing styles and at the ways we publish, then we will see that we are greatly affected. The ways that we write, that we promote our approaches and that we use the concepts of our chosen approaches will bear the traces of this wider culture for a simple reason: academic capitalism needs successful academic capitalists in order to thrive.

However, there are ways of minimalizing the impact of wider culture. I know this because I was a member of the Department of Social Sciences at Loughbourough which Peter Golding led for fourteen years. Peter believed passionately that the members of the Department, we should do the sort of work, of research work which individually we cared about. We should not try to do the sort of work which we thought that the managers might like, or which might appeal to the auditors within our discipline might like. His philosophy, which I think is a great philosophy, was that if you care about your research, then you will do your best work; and what matters is doing the best research that we can. Peter was greatly respected, even loved, within the Department of Social Sciences, which under his guidance was a very happy and successful department.

But in the conditions of academic capitalism, matters are seldom permitted to rest, but we are constantly encouraged to seek further profit, further success. Peter was told he could not remain Head of Department, but had to seek further promotion within the university (which he did not want and the Department did not want).

In effect, Peter was forced to give up the headship of the Department and accept a very senior position in the university. And then suddenly, the management took this position away from him: I can only assume 
that they wanted the position to be filled by someone who really believed in the capitalist rhetoric of competition and profit.

Everyone who knows Peter will report that he is a generous, bouncy and confident person. But he was deflated and deeply wounded by the university's treatment. I have never known his so depressed and perplexed. He seemed unable to comprehend why he was being treated so cruelly. He could not remain not remain at Loughboroug- and we in Social Sciences lost not just a very fine academic, but a great leader and human being.

I mention this not just to embarrass Peter, but to emphasise that capitalism, even in the protected world of academia, is cruel. This is yet another reason why we should view academic success in present conditions as being compromised: it is success within conditions that are intrinsically unfair and cruel. If we celebrate the present as being the best times, we must not forget that it is also the worst of times.

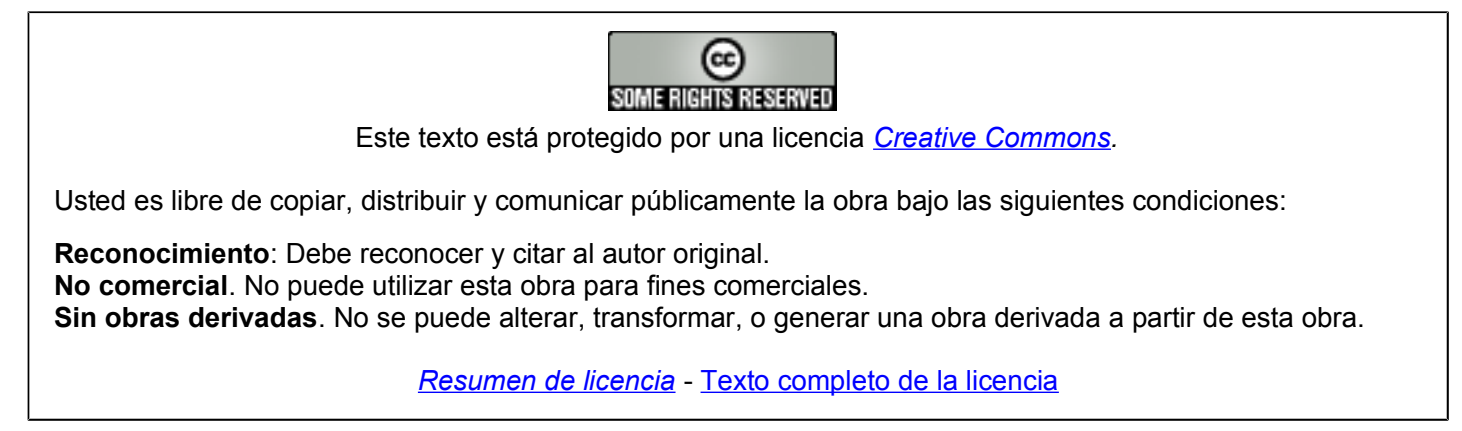

